\title{
Mitochondria-Targeted Approach: Remarkably Enhanced Cellular Bioactivities of TPP2a as Selective Inhibitor and Probe toward TrxR
}

Baoxia Liang, ' Weiyan Shao ${ }^{\dagger}$ Cuige Zhu, ${ }^{\dagger}$ Gesi Wen, ${ }^{\dagger}$ Xin Yue ${ }^{\dagger}$ Ruimin Wang, Junmin Quan, ${ }^{\ddagger}$ Jun Du, ${ }^{\dagger}$ and Xianzhang $\mathrm{Bu}^{\dagger *}$

", School of Pharmaceutical Sciences, Sun Yat-sen University, GuangZhou 510006, China.

", Laboratory of Chemical Genomics, School of Chemical Biology and Biotechnology Peking University Shenzhen Graduate School, Shenzhen 518055, China.

\section{Chemistry}

2. Experimental methods

3. Supporting Information Figures mentioned in text

4. ${ }^{1} \mathrm{H}$ NMR , ${ }^{13} \mathrm{C}$ NMR,${ }^{31} \mathrm{P}$ NMR and HRMS Spectra

5. Supporting Information References 


\section{Chemistry}

General Unless otherwise stated, all manipulations were carried out without taking precautions to exclude air and moisture. All chemicals and solvents (HPLC grade or better) were sourced commercially and used as received. Melting points were determined with OptiMelt MPA100. Mass spectra were recorded on Shimadzu LCMS-IT-TOF mass spectrometer. The HPLC analyses were performed on DIONEX Ultimate 3000 HPLC System, C18 column (250 mm $4.6 \mathrm{~mm}, 5 \mu \mathrm{m})$. The optimum HPLC separation was achieved on proper mode with a mobile phase composed of methanol, acetonitrile, and $0.1 \%$ trifluoroacetic acid at a flow rate of $1 \mathrm{~mL} \mathrm{~min}^{-1}$. The ${ }^{1} \mathrm{H},{ }^{13} \mathrm{C}$ and ${ }^{31} \mathrm{P}$ NMR spectra were recorded using tetra-methylsilane and phosphoric acid as the internal standard on a Bruker BioSpin GmbH spectrometer at 400, 101 and $162 \mathrm{MHz}$, respectively; and the coupling constants are reported in hertz. The following abbreviations were used to explain the multiplicities: s, singlet; d, doublet; t, triplet; dd, double doublet; m, multiplet, br, broad. The reactions were followed by thinlayer chromatography (TLC) on glass-packed precoated silica gel plates and visualized in an iodine chamber or with a UV lamp.

Synthesis of M1 Acetyl acetone $(10 \mathrm{~g}, 100 \mathrm{mmol})$ and boron trioxide $(0.49 \mathrm{~g}, 7.0$ mmol, 0.7 eq.) were mixed and stirred in ethyl acetate at $70^{\circ} \mathrm{C}$ for $30 \mathrm{~min}$, then vanillin (1.52 g, $10 \mathrm{mmol})$ and tributyl borate $(2.3 \mathrm{~g}, 10 \mathrm{mmol})$ were added and the mixture was stirred for further $30 \mathrm{~min}$. Next, n-butylamine $(0.73 \mathrm{~g}, 10 \mathrm{mmol})$ dissolved in dry ethyl acetate $(3.0 \mathrm{~mL})$ was added dropwisely, the mixture was stirred for $2.5 \mathrm{~h}$ at $85^{\circ} \mathrm{C}$. After that, Hydrochloric acid $\left(1.0 \mathrm{~mol} \mathrm{~L}^{-1}, 60^{\circ} \mathrm{C}\right)$ was added and the organic phase was separated and washed with water, dried with $\mathrm{Na}_{2} \mathrm{SO}_{4}$, and 
evaporated in vacuo after filtration. The raw material was purified by flash chromatography on silica gel using the eluent petroleum ether-ethyl acetate to give M1 (1.05 g, 45\% yield) as a yellow solid: m.p. 144.0-145.3 ${ }^{\circ} \mathrm{C} .{ }^{1} \mathrm{H}$ NMR (400 MHz, $\left.\left(\mathrm{CD}_{3}\right)_{2} \mathrm{SO}\right) \delta 15.73(\mathrm{~s}, 1 \mathrm{H}), 9.60(\mathrm{~s}, 1 \mathrm{H}), 7.49(\mathrm{~d}, \mathrm{~J}=16.0 \mathrm{~Hz}, 1 \mathrm{H}), 7.29(\mathrm{~s}, 1 \mathrm{H}), 7.11$ $(\mathrm{d}, \mathrm{J}=8.1 \mathrm{~Hz}, 1 \mathrm{H}), 6.81(\mathrm{~d}, \mathrm{~J}=8.1 \mathrm{~Hz}, 1 \mathrm{H}), 6.64(\mathrm{~d}, \mathrm{~J}=15.9 \mathrm{~Hz}, 1 \mathrm{H}), 5.85(\mathrm{~s}, 1 \mathrm{H})$, $3.82(\mathrm{~s}, 3 \mathrm{H}), 2.12(\mathrm{~s}, 3 \mathrm{H}) .{ }^{13} \mathrm{C} \mathrm{NMR}\left(101 \mathrm{MHz}, \mathrm{CDCl}_{3}\right) \delta 196.96,178.02,147.78$, $146.85,140.10,127.66,122.65,120.31,114.86,109.57,100.68,55.94,26.79$ ppm. HRMS (ESI) $\mathrm{m} / \mathrm{z}[\mathrm{M}+\mathrm{Na}]^{+}$for $\mathrm{C}_{13} \mathrm{H}_{14} \mathrm{O}_{4}$ predicted 257.0784, measured 257.0661; HPLC purity of $96.12 \%$.

Synthesis of 2a M1 (0.47 g, $2.0 \mathrm{mmol})$ and boric anhydride (0.12 g, $1.7 \mathrm{mmol}$, 0.7eq.) were dissolved in ethyl acetate and stirred at $70^{\circ} \mathrm{C}$ for $30 \mathrm{~min}$. Then 5-methyl-2-furaldehyde $(0.22 \mathrm{~g}, 2.0 \mathrm{mmol})$ and tributyl borate $(0.46 \mathrm{~g}, 2.0 \mathrm{mmol})$ were added, and the mixture was stirred for $30 \mathrm{~min}$. After that, $\mathrm{n}$-butylamine $(0.15 \mathrm{~g}$, $2.0 \mathrm{mmol}$ ) dissolved in ethyl acetate was added dropwise. After increasing the temperature to $85^{\circ} \mathrm{C}$, stirring was continued for $2.5 \mathrm{~h}$. The mixture was then hydrolyzed by adding aqueous $\mathrm{HCl}\left(1.0 \mathrm{~mol} \mathrm{~L}^{-1}\right)$ and stirring at $60{ }^{\circ} \mathrm{C}$ for $30 \mathrm{~min}$. The organic layer was separated, and the aqueous layer was extracted with ethyl acetate three times. The combined organic layers were washed with water until neutral. The solvent was removed in vacuo. The crude products were purified by flash column to give $2 \mathrm{a}(0.33 \mathrm{~g}, 50 \%$ yield $)$ as an orange red solid: m.p. $123.3-124.7^{\circ} \mathrm{C} .{ }^{1} \mathrm{H}$ NMR $(400$ $\left.\mathrm{MHz},\left(\mathrm{CD}_{3}\right)_{2} \mathrm{SO}\right) \delta 7.56(\mathrm{~d}, \mathrm{~J}=15.9 \mathrm{~Hz}, 1 \mathrm{H}), 7.34(\mathrm{dd}, \mathrm{J}=16.4,8.7 \mathrm{~Hz}, 2 \mathrm{H}), 7.14(\mathrm{dd}$, $\mathrm{J}=8.2,1.7 \mathrm{~Hz}, 1 \mathrm{H}), 6.93-6.74(\mathrm{~m}, 3 \mathrm{H}), 6.73(\mathrm{~d}, \mathrm{~J}=15.8 \mathrm{~Hz}, 1 \mathrm{H}), 6.46(\mathrm{~d}, \mathrm{~J}=15.6$ 
$\mathrm{Hz}, 1 \mathrm{H}), 6.30(\mathrm{~d}, \mathrm{~J}=3.2 \mathrm{~Hz}, 1 \mathrm{H}), 6.09(\mathrm{~s}, 1 \mathrm{H}), 3.84(\mathrm{~s}, 3 \mathrm{H}), 2.36(\mathrm{~s}, 3 \mathrm{H}) .{ }^{13} \mathrm{C} \mathrm{NMR}$ (101 MHz, (CD $\left.)_{2} \mathrm{SO}\right) \delta 183.79,181.79,155.66,149.77,149.41,147.98,141.04$, $126.43,126.26,123.20,121.03,119.58,117.63,115.68,111.27,109.63,101.18,55.65$ $13.62 \mathrm{ppm}$. HRMS (ESI) $\mathrm{m} / \mathrm{z}[\mathrm{M}+\mathrm{Na}]{ }^{+}$for $\mathrm{C}_{19} \mathrm{H}_{18} \mathrm{O}_{5}$ predicted 349.1046 , measured 349.0842; HPLC purity of $97.22 \%$.

Synthesis of M2 To a solution of $2 \mathrm{a}(0.33 \mathrm{~g}, 1 \mathrm{mmol})$ in acetone $(30 \mathrm{~mL})$, anhydrous $\mathrm{K}_{2} \mathrm{CO}_{3}(1.10 \mathrm{~g}, 8.0 \mathrm{mmol}, 8$ eq. $)$ and 1,10-dibromodecane(2.40 g, 8.0 mmol, 8 eq.) were added, the mixture was stirred overnight at RT. Then $\mathrm{K}_{2} \mathrm{CO}_{3}$ was removed by filtration, and the solvent was evaporated under the vacuum. The crude products were purified by flash chromatography on silica gel using the eluent petroleum ether-ethyl acetate to give M2 (0.38 g, 70\% yield) as orange solid: m.p. 89.1-90.3 ${ }^{\circ} \mathrm{C} .{ }^{1} \mathrm{H}$ NMR $\left(400 \mathrm{MHz},\left(\mathrm{CD}_{3}\right)_{2} \mathrm{SO}\right) \delta 7.58(\mathrm{~d}, \mathrm{~J}=15.8 \mathrm{~Hz}, 1 \mathrm{H}), 7.35(\mathrm{dd}, \mathrm{J}$ $=13.7,8.5 \mathrm{~Hz}, 2 \mathrm{H}), 7.23(\mathrm{~d}, \mathrm{~J}=8.4 \mathrm{~Hz}, 1 \mathrm{H}), 7.00(\mathrm{~d}, \mathrm{~J}=8.4 \mathrm{~Hz}, 1 \mathrm{H}), 6.86(\mathrm{~d}, \mathrm{~J}=3.2$ $\mathrm{Hz}, 1 \mathrm{H}), 6.79(\mathrm{~d}, \mathrm{~J}=15.9 \mathrm{~Hz}, 1 \mathrm{H}), 6.47(\mathrm{~d}, \mathrm{~J}=15.6 \mathrm{~Hz}, 1 \mathrm{H}), 6.31(\mathrm{~d}, \mathrm{~J}=2.4 \mathrm{~Hz}, 1 \mathrm{H})$, $6.11(\mathrm{~s}, 1 \mathrm{H}), 4.00(\mathrm{t}, \mathrm{J}=6.5 \mathrm{~Hz}, 2 \mathrm{H}), 3.82(\mathrm{~s}, 3 \mathrm{H}), 3.52(\mathrm{t}, \mathrm{J}=6.7 \mathrm{~Hz}, 2 \mathrm{H}), 2.36(\mathrm{~s}, 3 \mathrm{H})$, $1.88-1.66(\mathrm{~m}, 4 \mathrm{H}), 1.45-1.17(\mathrm{~m}, 12 \mathrm{H}) .{ }^{13} \mathrm{C} \mathrm{NMR}\left(101 \mathrm{MHz}, \mathrm{CDCl}_{3}\right) \delta$ 183.51, $182.60,155.53,150.71,150.40,149.56,140.41,127.94,126.77,122.64,122.05$, $120.05,116.66,112.48,110.30,109.16,101.62,69.02,56.05,34.00,32.81,29.39$, 29.33, 29.30, 29.04, 28.73, 28.15, 25.90, $13.96 \mathrm{ppm}$. HRMS (ESI) $\mathrm{m} / \mathrm{z}[\mathrm{M}+\mathrm{Na}]^{+}$for $\mathrm{C}_{29} \mathrm{H}_{37} \mathrm{BrO}_{5}$ predicted 567.1717, measured 567.1732; HPLC purity of 98.44\%.

Synthesis of TPP2a The mixture of M2 (0.38 g, $0.69 \mathrm{mmol})$ and PPh $3(0.90 \mathrm{~g}, 3.45$ mmol, 5 eq.) in $15 \mathrm{~mL}$ acetonitrile was stirred for $2 \mathrm{~d}$ at $100^{\circ} \mathrm{C}$. Evaporation of the 
solvent, the solid was washed with ethyl acetate. The crude products were purified by flash chromatography on silica gel using the eluent ethyl acetate-methanol to afford the desired product TPP $2 \mathrm{a}(0.25 \mathrm{~g}, 45 \%$ yield $)$ as a crimson solid: m.p. $67.5-68.4^{\circ} \mathrm{C}$. ${ }^{1} \mathrm{H}$ NMR (400 MHz, (CD3)2SO) $\delta$ 7.93-7.74 (m, 15H), $7.58(\mathrm{~d}, \mathrm{~J}=15.8 \mathrm{~Hz}, 1 \mathrm{H}), 7.37$ $(\mathrm{d}, \mathrm{J}=15.6 \mathrm{~Hz}, 1 \mathrm{H}), 7.34(\mathrm{~d}, \mathrm{~J}=1.8 \mathrm{~Hz}, 1 \mathrm{H}), 7.23(\mathrm{dd}, \mathrm{J}=8.4,1.7 \mathrm{~Hz}, 1 \mathrm{H}), 7.00(\mathrm{~d}, \mathrm{~J}$ $=8.4 \mathrm{~Hz}, 1 \mathrm{H}), 6.86(\mathrm{~d}, \mathrm{~J}=3.2 \mathrm{~Hz}, 1 \mathrm{H}), 6.80(\mathrm{~d}, \mathrm{~J}=15.9 \mathrm{~Hz}, 1 \mathrm{H}), 6.47(\mathrm{~d}, \mathrm{~J}=15.6 \mathrm{~Hz}$ 1H), $6.31(\mathrm{~m}, 1 \mathrm{H}), 6.12(\mathrm{~s}, 1 \mathrm{H}), 3.99(\mathrm{t}, 2 \mathrm{H}), 3.81(\mathrm{~s}, 3 \mathrm{H}), 3.55(\mathrm{t}, 2 \mathrm{H}), 2.36(\mathrm{~s}, 3 \mathrm{H})$, $1.70(\mathrm{~m}, 2 \mathrm{H}), 1.53-1.21(\mathrm{~m}, 14 \mathrm{H}) .{ }^{13} \mathrm{C} \mathrm{NMR}\left(101 \mathrm{MHz},\left(\mathrm{CD}_{3}\right)_{2} \mathrm{SO}\right) \delta 183.39,182.20$ $155.75,150.39,149.74,149.14,140.52,134.83(4 \mathrm{C}), 133.54(6 \mathrm{C}), 130.19(6 \mathrm{C}), 127.44$, $126.61,122.98,121.95,119.55,118.98,118.13,117.79,112.61,110.63,109.68$, $101.32,68.18,55.67,29.81,29.65,28.76,28.59,28.03,25.43,21.68,20.43,19.94$, 13.65 ppm. ${ }^{31} \mathrm{P}$ NMR (162 MHz, $\left.\left(\mathrm{CD}_{3}\right)_{2} \mathrm{SO}\right) \delta 24.08$. HRMS (ESI) $\mathrm{m} / \mathrm{z}[\mathrm{M}]{ }^{+}$for $\mathrm{C}_{47} \mathrm{H}_{52} \mathrm{O}_{5} \mathrm{P}^{+}$predicted 727.3547 , measured 727.3548; HPLC purity of $99.07 \%$.

Synthesis of TPPOH A solution of 10-bromo-1-decanol (0.24 g, $1 \mathrm{mmol})$ in dry acetonitrile $(50 \mathrm{~mL})$ was treated with triphenylphosphine $(1.31 \mathrm{~g}, 5 \mathrm{mmol})$. The solution was refluxed with stirring for $48 \mathrm{~h}$. The solvent was removed in a vacuum, and the crude product was subjected to chromatography on silica gel (EtOAc, $\mathrm{MeOH}$ ) to yield compound TPPOH as a colorless oil (0.30 g, 60\%). ${ }^{1} \mathrm{H}$ NMR (400 MHz, $\left.\left(\mathrm{CD}_{3}\right)_{2} \mathrm{SO}\right) \delta 8.19-7.57(\mathrm{~m}, 15 \mathrm{H}), 3.56(\mathrm{~m}, 2 \mathrm{H}), 3.40-3.35(\mathrm{~m}, 2 \mathrm{H}), 1.57-1.36(\mathrm{~m}, 6 \mathrm{H})$, $1.18(\mathrm{~m}, 10 \mathrm{H}) .{ }^{13} \mathrm{C}$ NMR (101 MHz, $\left.\left(\mathrm{CD}_{3}\right)_{2} \mathrm{SO}\right) \delta 134.83(4 \mathrm{C}), 133.60(6 \mathrm{C})$, 130.26(6C), 118.99, 118.14, 60.65, 32.46, 29.82, 29.66, 28.86, 28.83, 28.62, 28.05, 25.44, $21.72 \mathrm{ppm}$. HRMS (ESI) $\mathrm{m} / \mathrm{z}[\mathrm{M}]{ }^{+}$for $\mathrm{C}_{28} \mathrm{H}_{36} \mathrm{OP}^{+}$predicted 419.2498, 
measured 419.2502; HPLC purity of $98.05 \%$.

\section{Experimental methods}

Sample preparation TPP2a, 2a, TPPOH and DNCB were dissolved in DMSO to obtain stock solutions $(10 \mathrm{mM})$. NACs, DTT, metal salts were dissolved in double distilled water to obtain stock solutions (10 mM); TrxR, Trx, HRP, SOD, BSA, tryspin, tubulin are dissolved in PBS buffer to obtain stock solutions $(10 \mu \mathrm{M})$. These stock solutions were diluted with PBS buffer ( $\mathrm{pH}$ 7.4) to the desired concentration before use, and the DMSO is no more than $1 \%(\mathrm{v} / \mathrm{v})$ in all experiments. For fluorescence detection, TrxR, Trx are activated by DTT $(10 \mu \mathrm{M})$ at room temperature for $30 \mathrm{~min}$ before use; for consistency, other proteins are also added DTT $(10 \mu \mathrm{M})$ at room temperature for $30 \mathrm{~min}$ before use.

Molecular docking The complex model of TrxR with TPP2a was generated by the MOE software. The protein structure was extracted from the PDB file (PBD code 2ZZB) of the human TrxR, ${ }^{1}$ and the ligand conformer was generated by MOE using the MMFF94x force field. The ligand was manually covalent to Sec498 residue of TrxR, and the final structure of the ligand with the free C-terminal tail (from reside Ile 492 to Gly 499) of TrxR was generated by conformational search module with the LowModeMD method. ${ }^{2}$ The structural figures were drawn in PyMOL. ${ }^{3}$

RNA interference Small interfering RNAs (siRNA) that target human TrxR2 was based on nucleotides 1160-1178 (GTCTGAATTTGGAGAAGGC) relative to the translation start sit. ${ }^{4}$ TrxR2-specific sense (5'-GUCUGAAUUUGGAGAAGGC-3') and antisense (3'-CAGACUUAAACCUCUUCCG-5') siRNA oligonucleotides were synthesized by RiboBio. The cells were seeded to 6-well plates. After incubation for $24 \mathrm{~h}$, the cells were transfected with siRNA for $3 \mathrm{~d}$ employing Lipofectamine 3000 (Invitrogen). The N-Control non-targeting siRNA (RiboBio) served as a negative control for siRNA activity. After three days, TrxR2 knockdown was determined by Western blotting.

Real-time RT-PCR analyses HeLa cells were plated in a 6-well dish and exposed to 
treatment with siRNA for $24 \mathrm{~h}$, the medium was removed and cells were rinsed twice with PBS. Total RNA was isolated and purified from HeLa cells by RNA Trizol extraction (Invitrogen). cDNA was produced using Taqman reverse transcription (Invitrogen) kits. The primers used in each reaction were as follows: TrxR2 forward 5' -GTTCCCACGACCGTCTTCAC-3 ' -GTGATAGACCTCAACATGCTCCTG -3' ; ; GAPDH, forward 5' -GCA CCG TCA AGG CTG AGA AC-3' and reverse 5' -TGG TGA AGA CGC CAG TGG A-3' (Sangon Biotech). Real-time RT-PCR experiments were performed using SYBR1Green Real-time PCR Master Mix (TOYOBO) according to the manufacturer' s instructions. Real-time PCR (QRT-PCR) was performed in triplicate on LightCyclerH 480 II (Roche). Primers were designed to be compatible with a single QRT-PCR thermal profile $\left(95{ }^{\circ} \mathrm{C}\right.$ for $10 \mathrm{~min}$, and 40 cycles of $95{ }^{\circ} \mathrm{C}$ for $30 \mathrm{~s}$ and $60{ }^{\circ} \mathrm{C}$ for $\left.1 \mathrm{~min}\right)$. After normalized to GAPDH gene, expression levels for each target gene were calculated using the comparative threshold cycle (CT) method. 


\section{Supporting Information Figures mentioned in text}

A

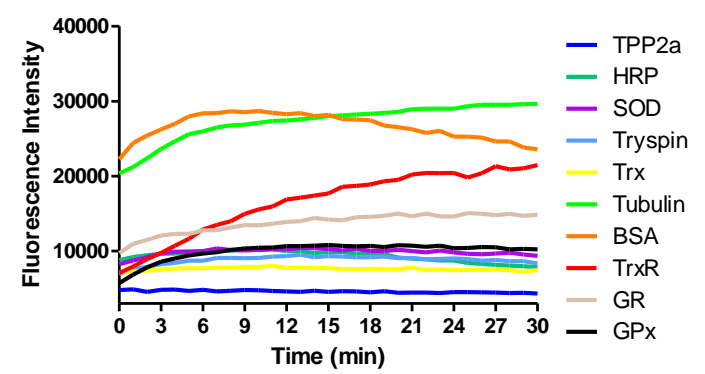

C

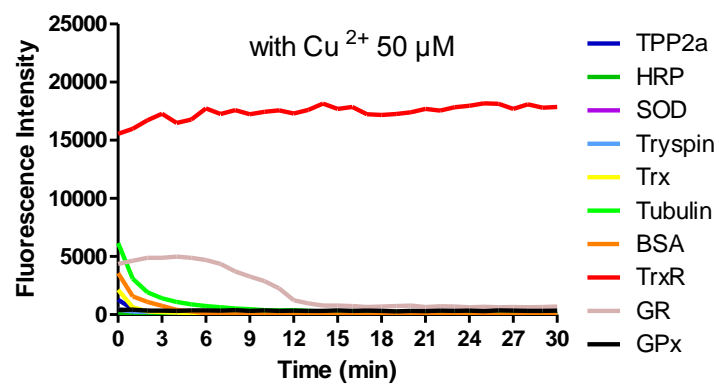

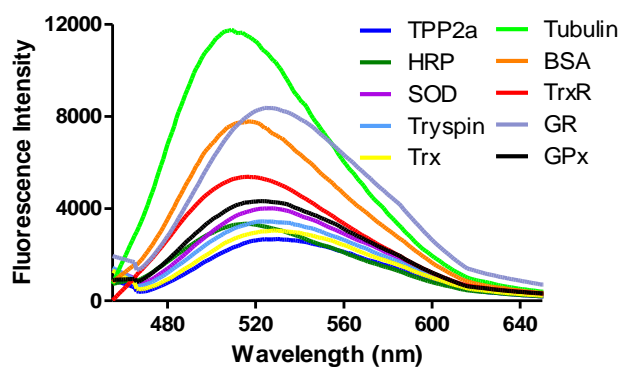

Figure S1. Fluorescence responses of TPP2a $(2.0 \mu \mathrm{M})$ to putative proteins with or without $\mathrm{Cu}^{2+}(50 \mu \mathrm{M})$. (A)Time course of the fluorecence changes of TPP2a in the presence of $1.0 \mu \mathrm{M}$ different proteins. (B) Fluorescent emission spectra of TPP2a to various proteins. (C)The effect of the $\mathrm{Cu}^{2+}$ to the fluorescence of TPP $2 \mathrm{a}$ with in different proteins. Fluorescent kinetics is recorded with $\lambda$ ex $=440 \mathrm{~nm}, \quad \lambda$ em $=520$ $\mathrm{nm}$. Fluorescent emission is recorded with $\lambda$ ex $=440 \mathrm{~nm}$. All spectra are recorded in PBS solution ( $\mathrm{pH} 7.4)$ containing $1 \%(\mathrm{v} / \mathrm{v})$ of DMSO at $37{ }^{\circ} \mathrm{C}$. 


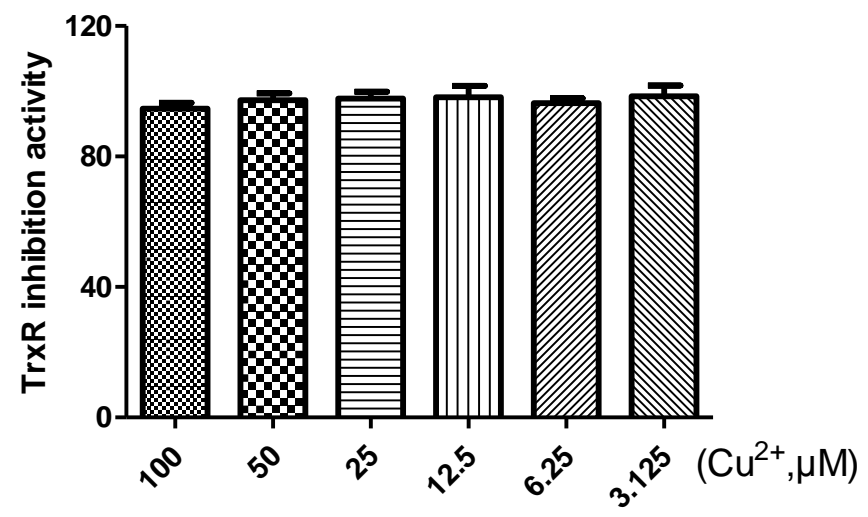

Figure S2. Effect of cupric acetate on thioredoxin reductase activity. The enzymes were incubated with the indicated concentrations of cupric acetate for $5 \mathrm{~min}$ at room temperature, and the TrxR activity was determined by DTNB assay. DTNB reduction was estimated spectrophoto-metrically at $412 \mathrm{~nm}$. 
A

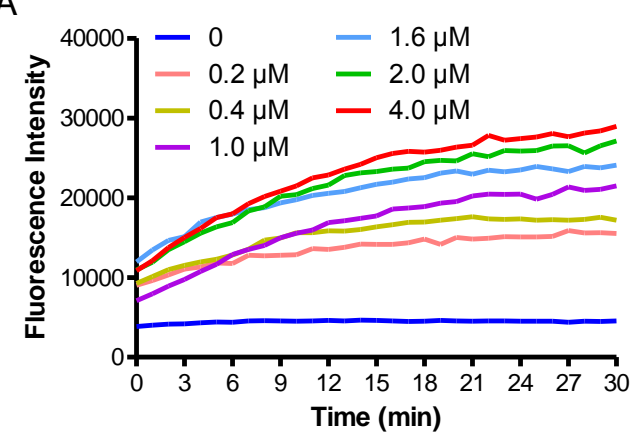

C

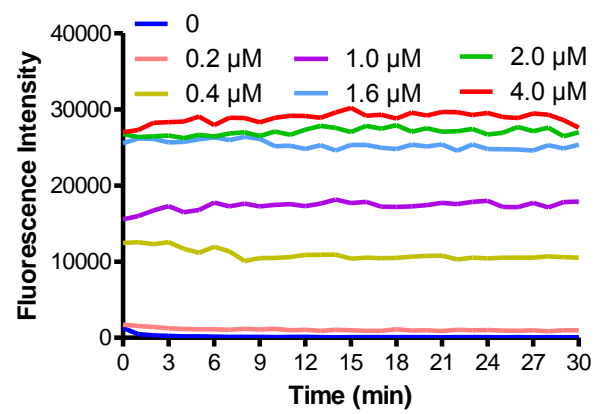

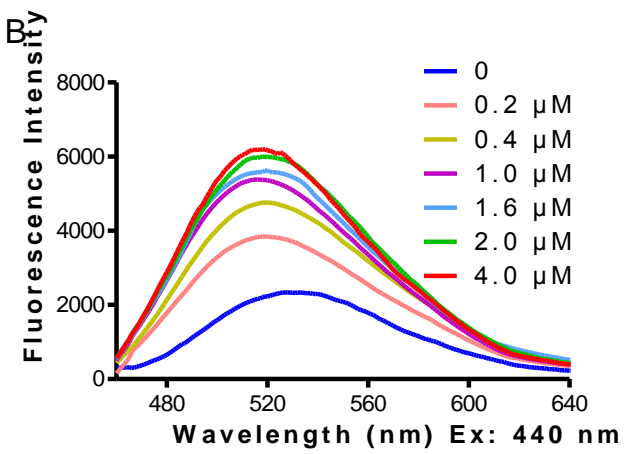

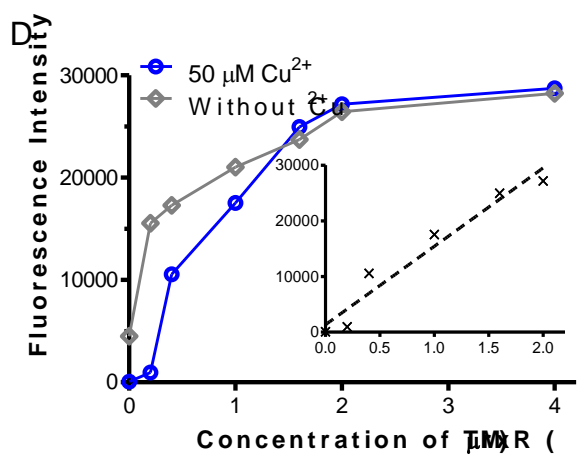

Figure S3. Fluorescence responses of TPP2a $(2.0 \mu \mathrm{M})$ to various concentrations of TrxR in the absence and presence of $\mathrm{Cu}^{2+}(50 \mu \mathrm{M})$. The fluorescence kinetics $(\mathrm{A})$ and emission spectra (B) were recorded. After the addition of $\mathrm{Cu}^{2+}$, the fluorescence kinetics were recorded again (C), and stable fluorescence intensity (30 min) was compared in the absence and presence of $\mathrm{Cu}^{2+}(\mathrm{D})$ inserts, linear regression of the dose-dependent response of TPP2a with TrxR in the presence of $\mathrm{Cu}^{2+}$. 
4. ${ }^{1} \mathrm{H}$ NMR , ${ }^{13} \mathrm{C}$ NMR,${ }^{31} \mathrm{P}$ NMR and HRMS Spectra
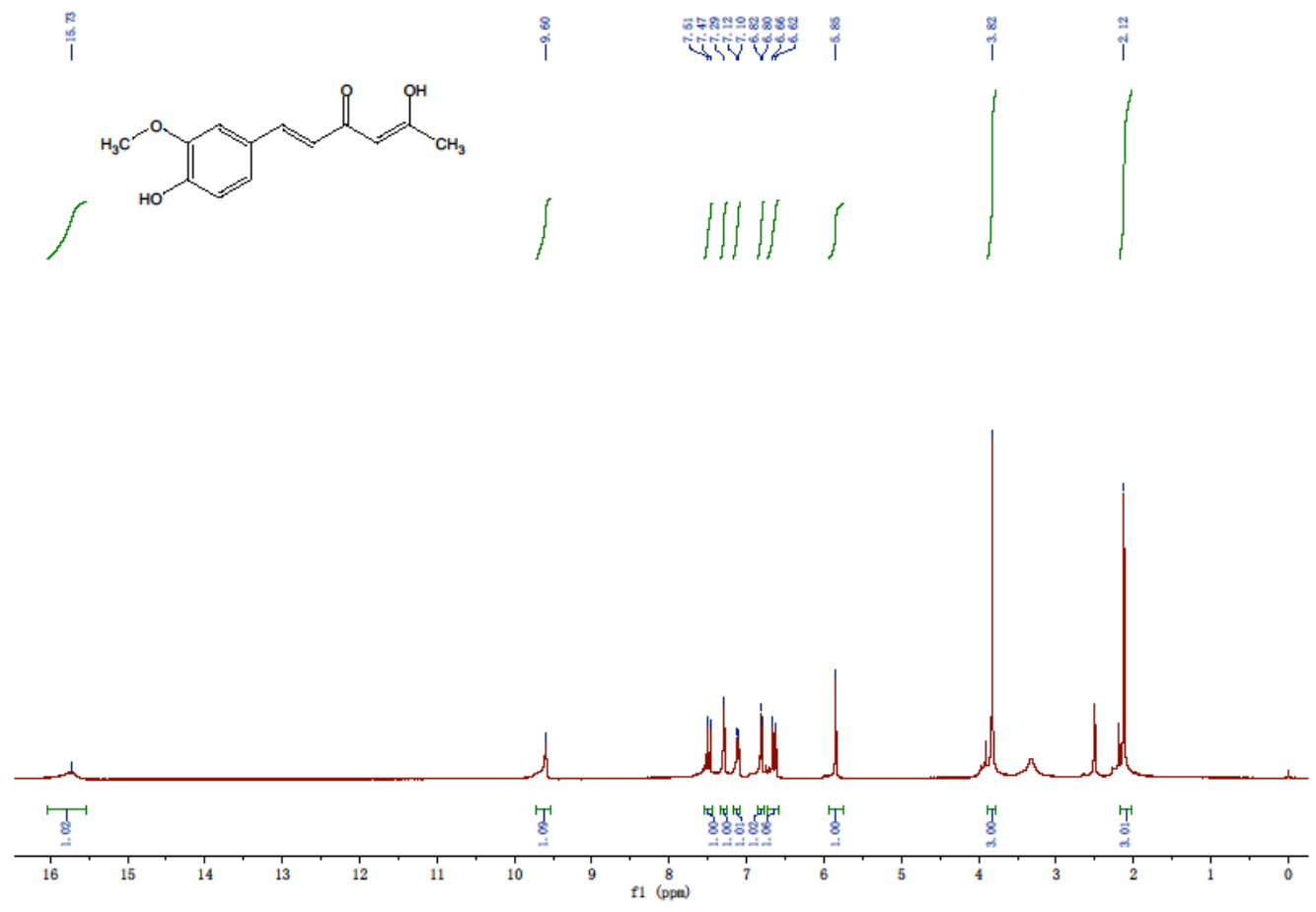

Figure S4. ${ }^{1} \mathrm{H}-\mathrm{NMR}$ spectrum of $\mathrm{M} 1 \mathrm{in}\left(\mathrm{CD}_{3}\right)_{2} \mathrm{SO}(400 \mathrm{MHz})$.
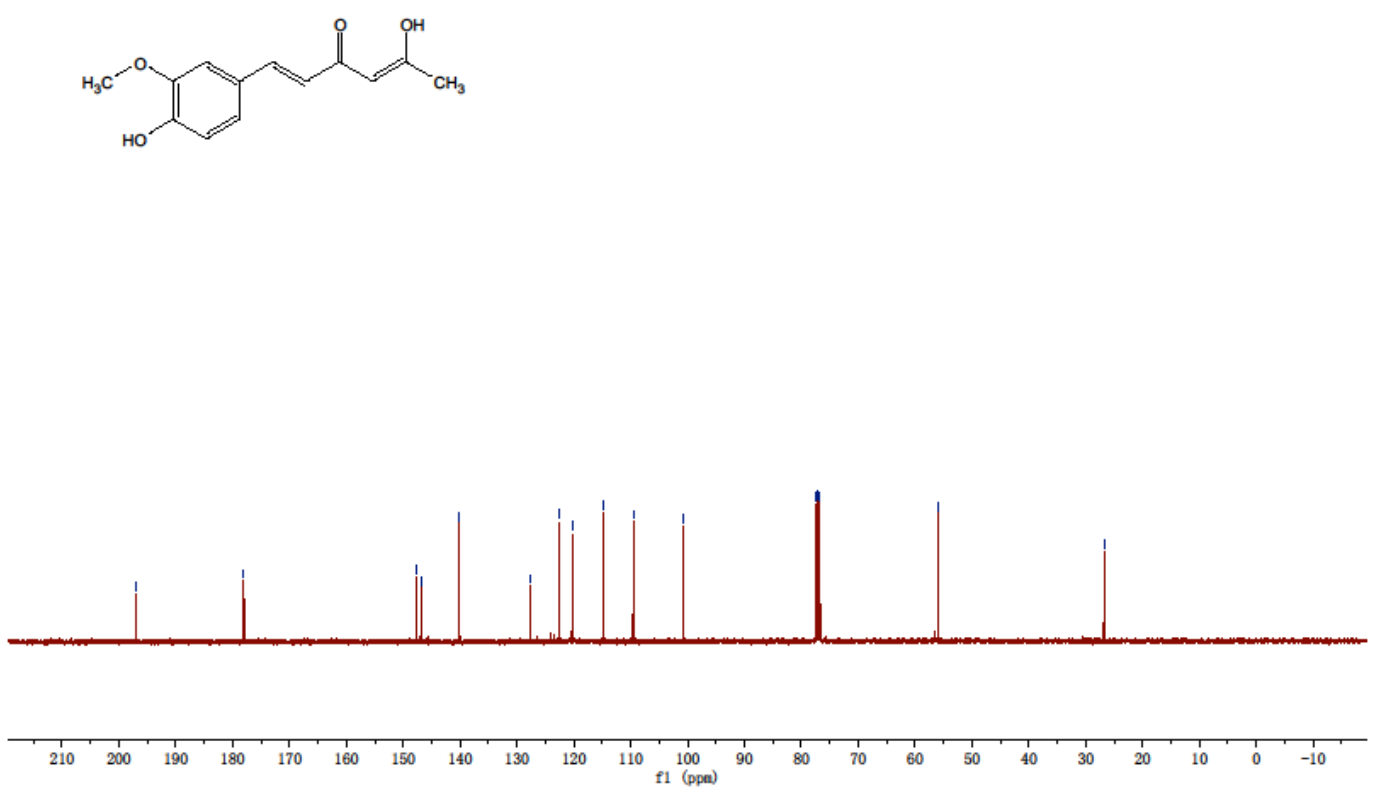

Figure S5. ${ }^{13} \mathrm{C}$ NMR spectrum of $\mathrm{M} 1$ in $\mathrm{CD}_{3} \mathrm{Cl}_{3}(101 \mathrm{MHz})$. 


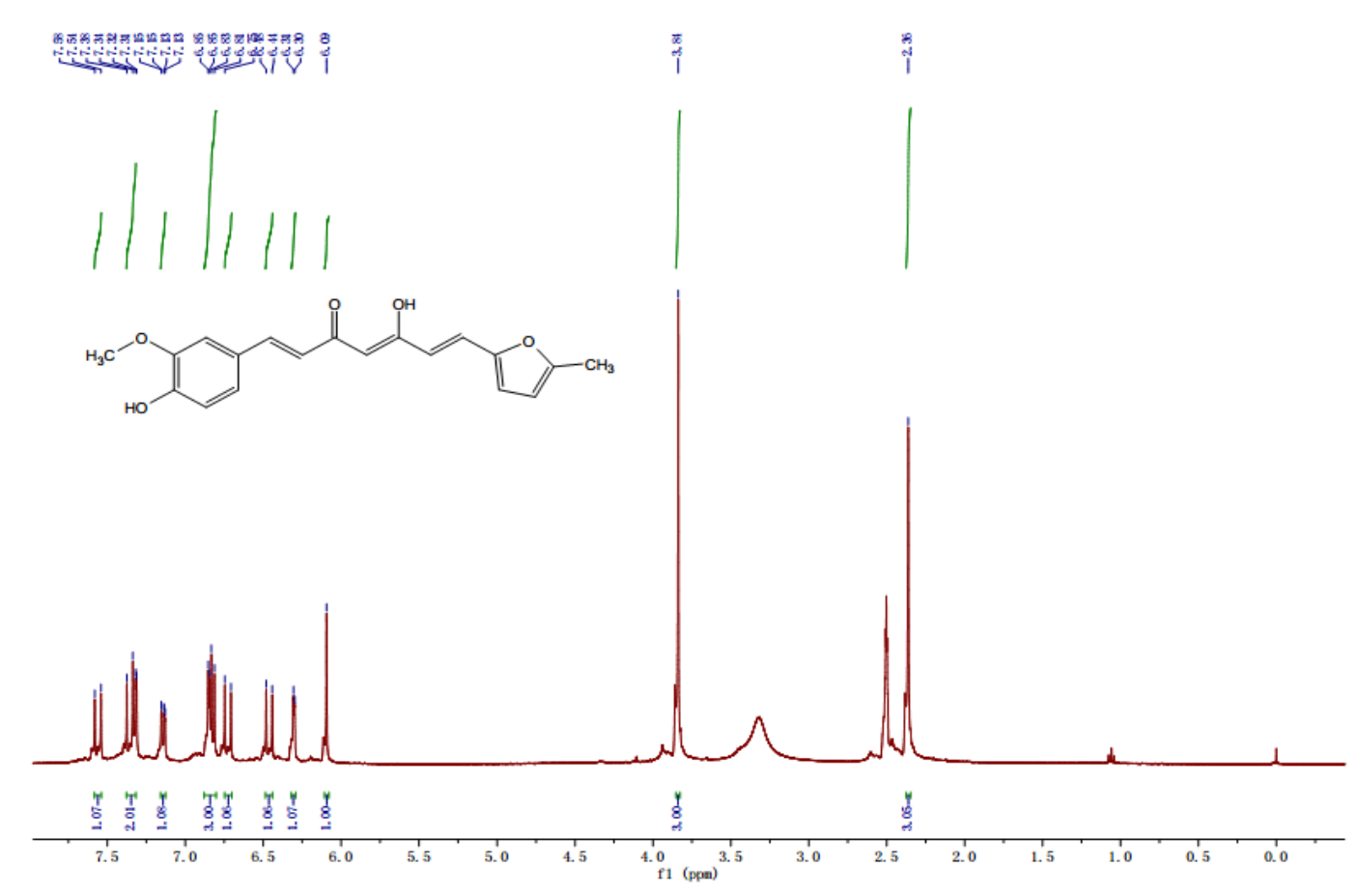

Figure S6. ${ }^{1} \mathrm{H}-\mathrm{NMR}$ spectrum of $2 \mathrm{a}$ in $\left(\mathrm{CD}_{3}\right)_{2} \mathrm{SO}(400 \mathrm{MHz})$.

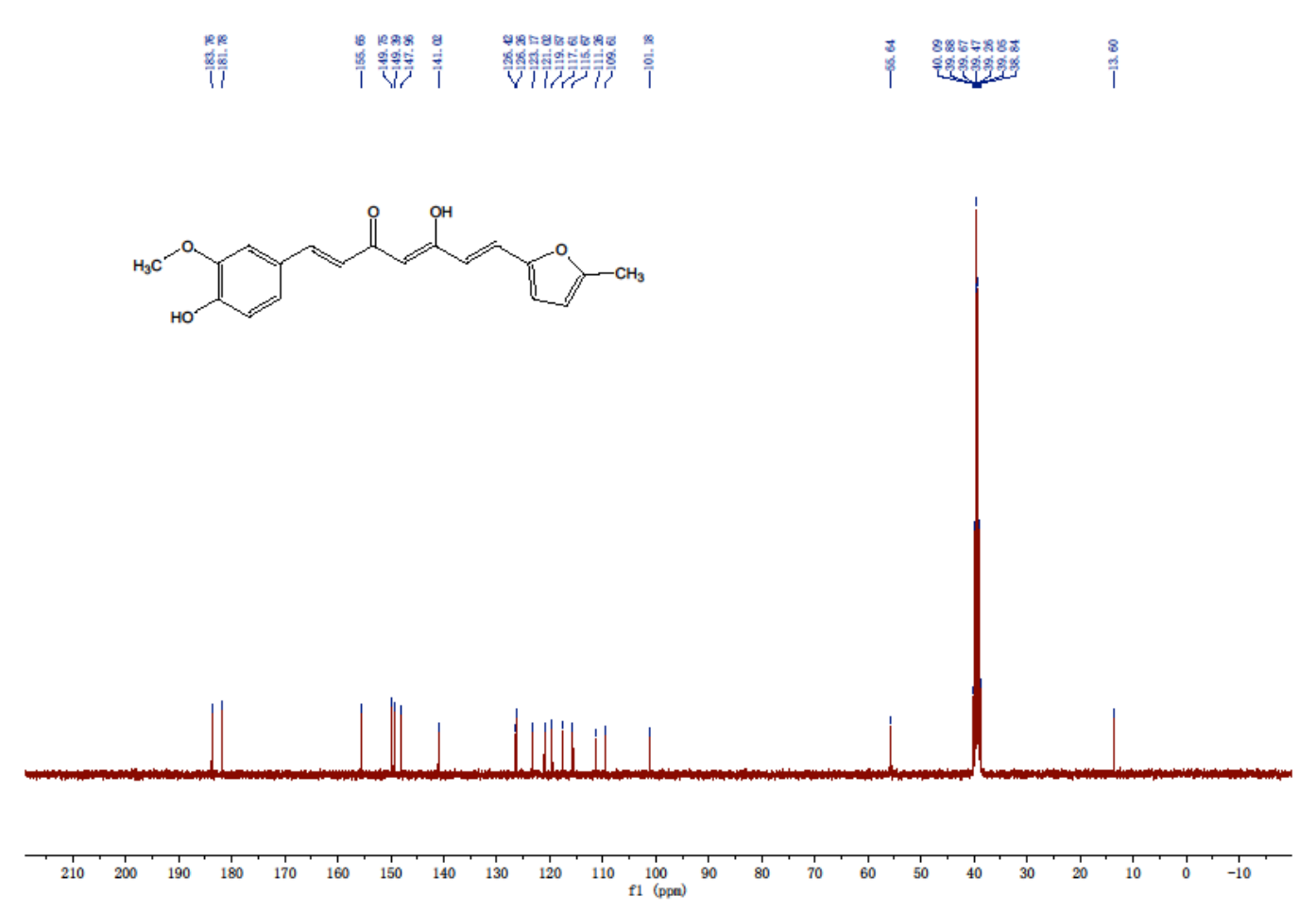

Figure S7. ${ }^{13} \mathrm{C}$ NMR spectrum of $2 \mathrm{a}$ in $\left(\mathrm{CD}_{3}\right)_{2} \mathrm{SO} .(101 \mathrm{MHz})$. 


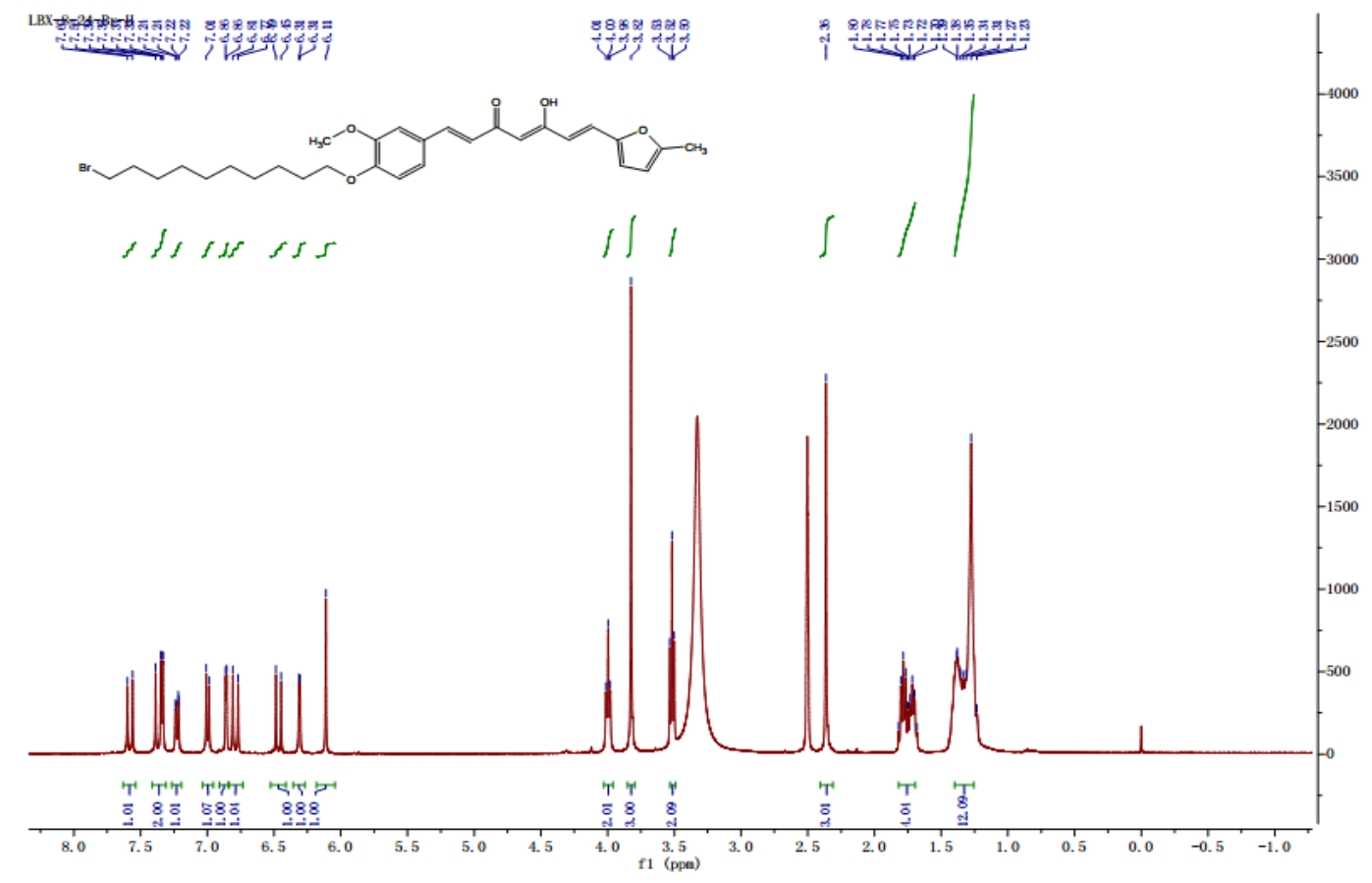

Figure S8. ${ }^{1} \mathrm{H}-\mathrm{NMR}$ spectrum of $\mathrm{M} 2$ in $\left(\mathrm{CD}_{3}\right)_{2} \mathrm{SO}(400 \mathrm{MHz})$.

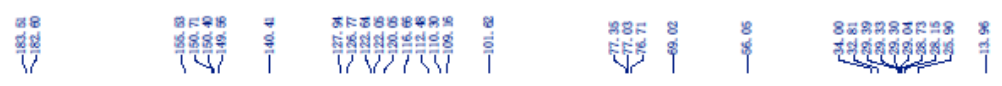
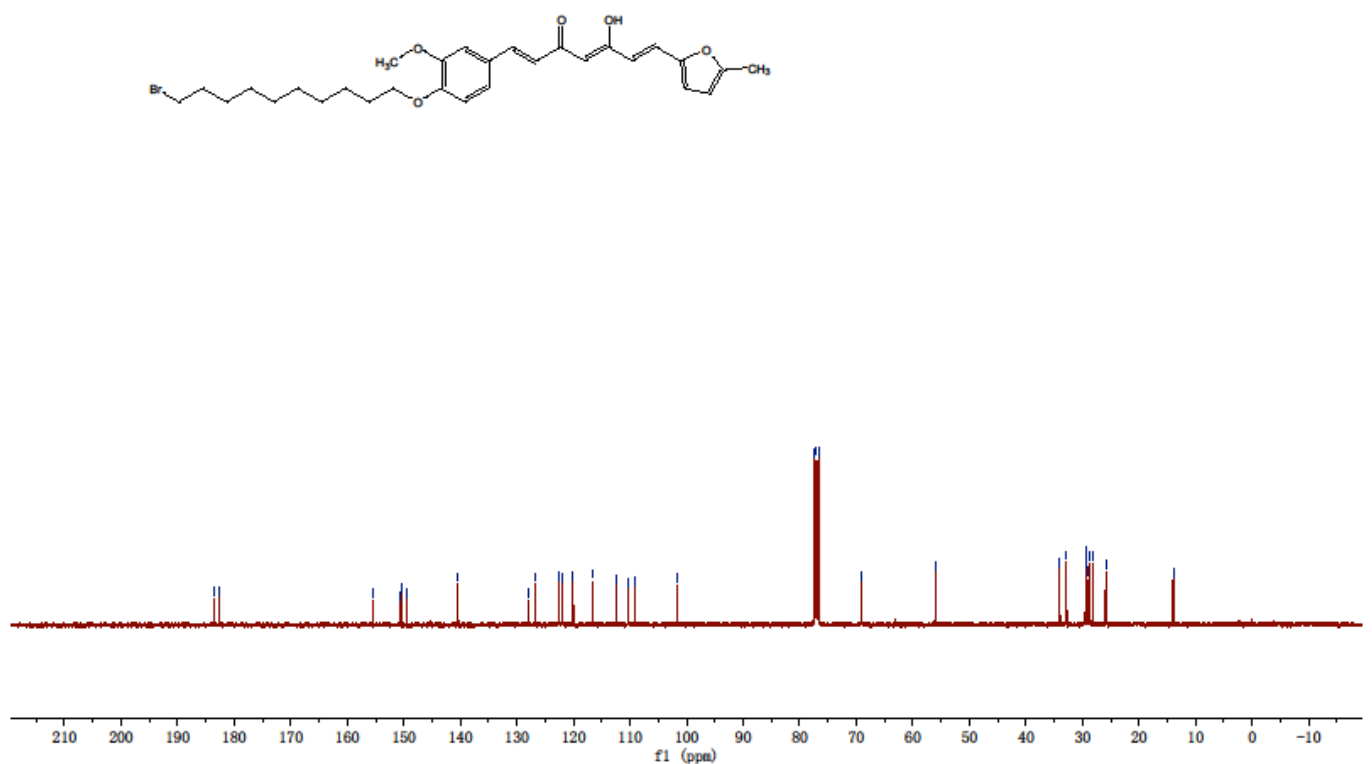

Figure S9. ${ }^{13} \mathrm{C}$ NMR spectrum of $\mathrm{M} 2$ in $\mathrm{CDCl}_{3}(101 \mathrm{MHz})$. 


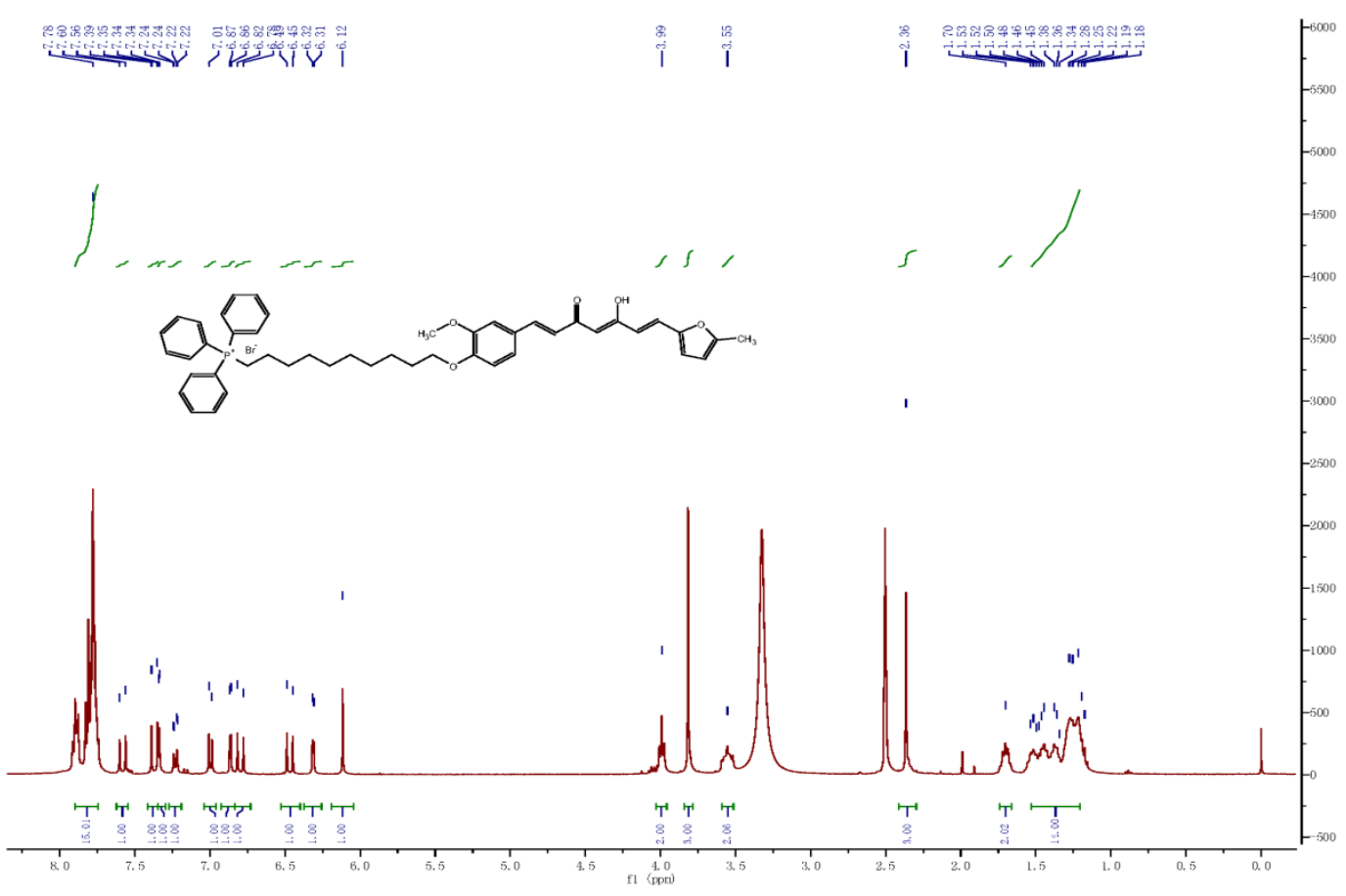

Figure S10. ${ }^{1} \mathrm{H}-\mathrm{NMR}$ spectrum of TPP2a in $\left(\mathrm{CD}_{3}\right)_{2} \mathrm{SO}(400 \mathrm{MHz})$.

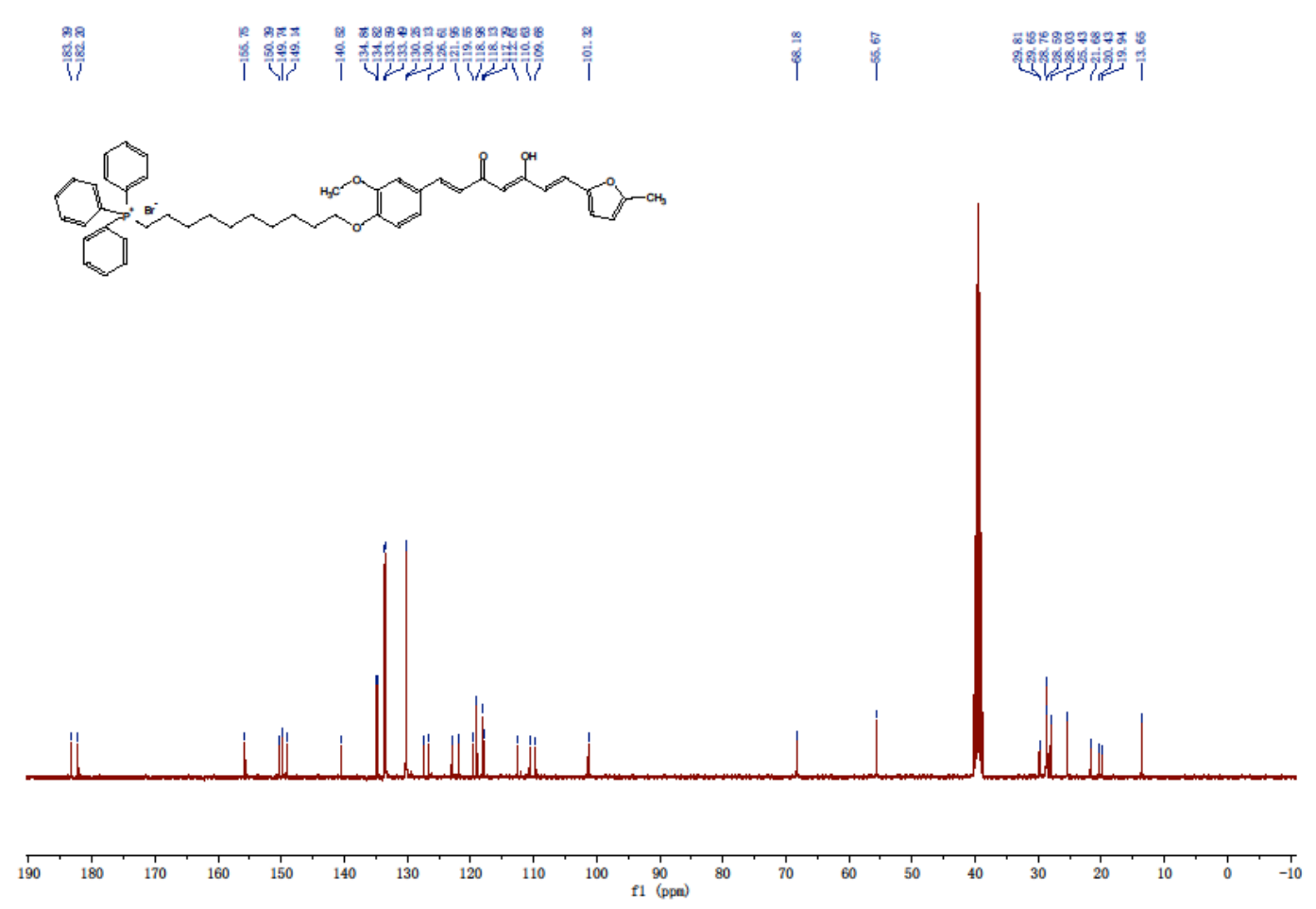

Figure S11. ${ }^{13} \mathrm{C}$ NMR spectrum of TPP-2a in $\left(\mathrm{CD}_{3}\right)_{2} \mathrm{SO}(101 \mathrm{MHz})$. 


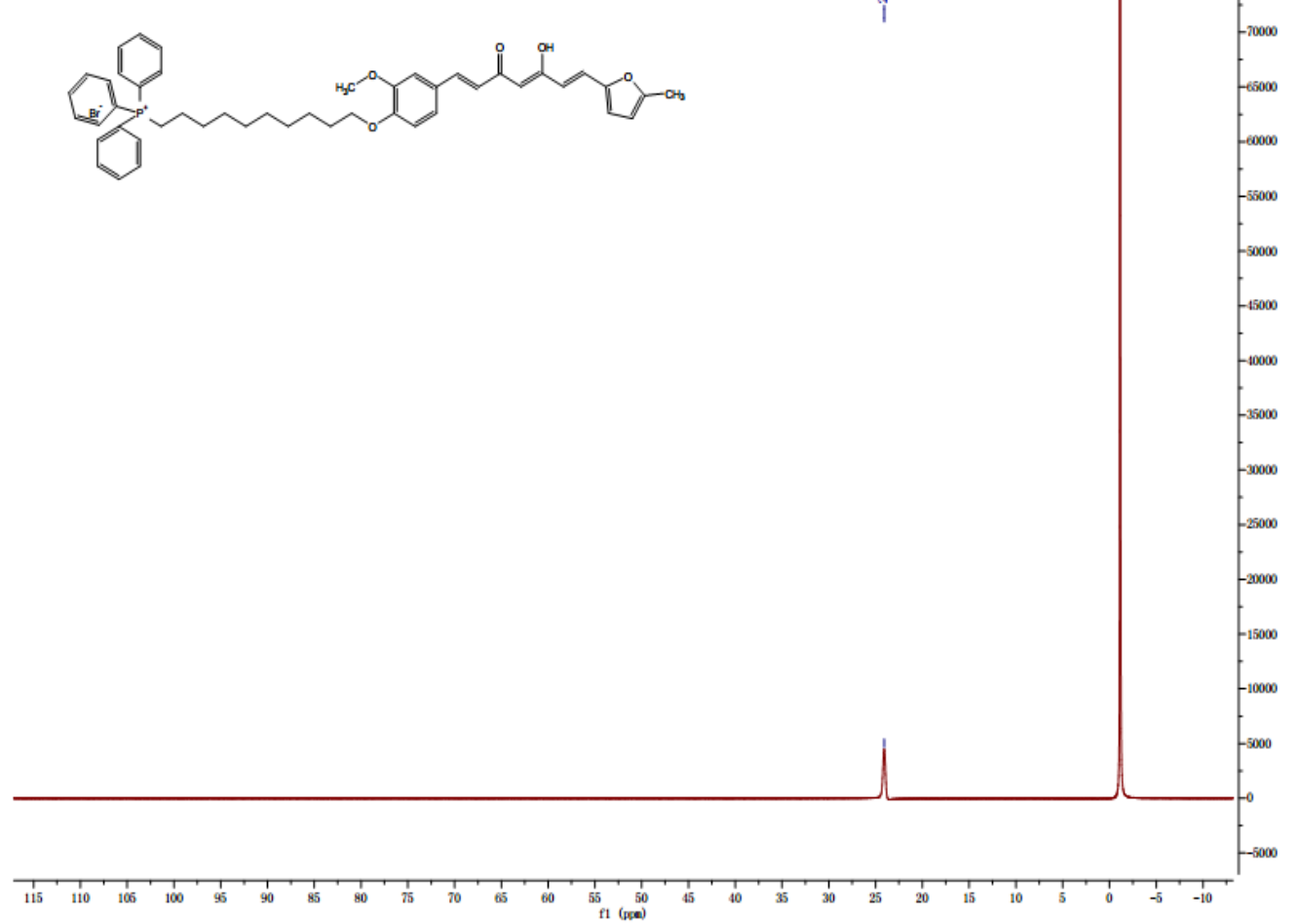

Figure S12. ${ }^{31} \mathrm{P}$ NMR spectrum of TPP2a in $\left(\mathrm{CD}_{3}\right)_{2} \mathrm{SO}(162 \mathrm{MHz})$.

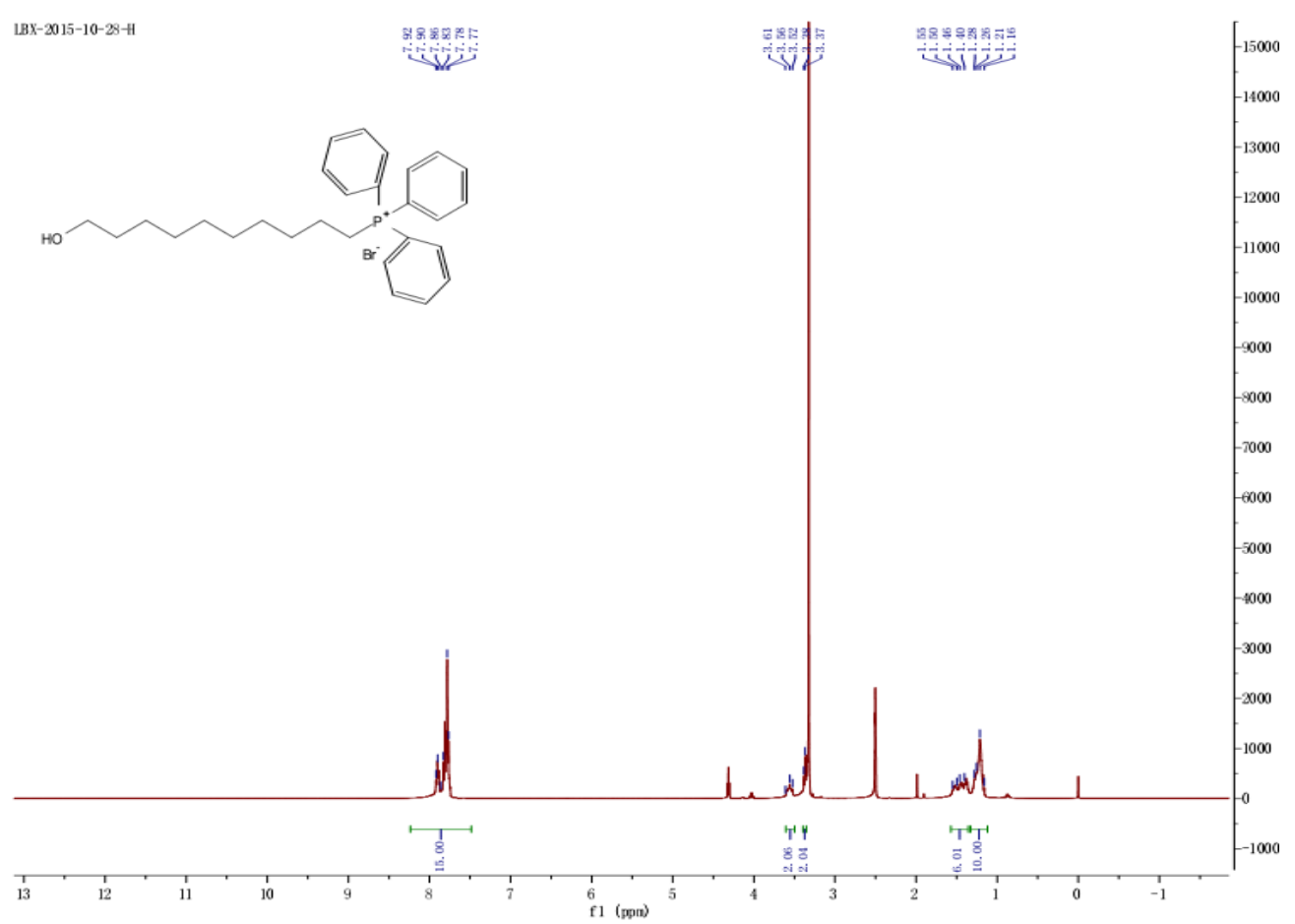

Figure S13. ${ }^{1} \mathrm{H}-\mathrm{NMR}$ spectrum of TPPOH in $\left(\mathrm{CD}_{3}\right)_{2} \mathrm{SO}(400 \mathrm{MHz})$. 


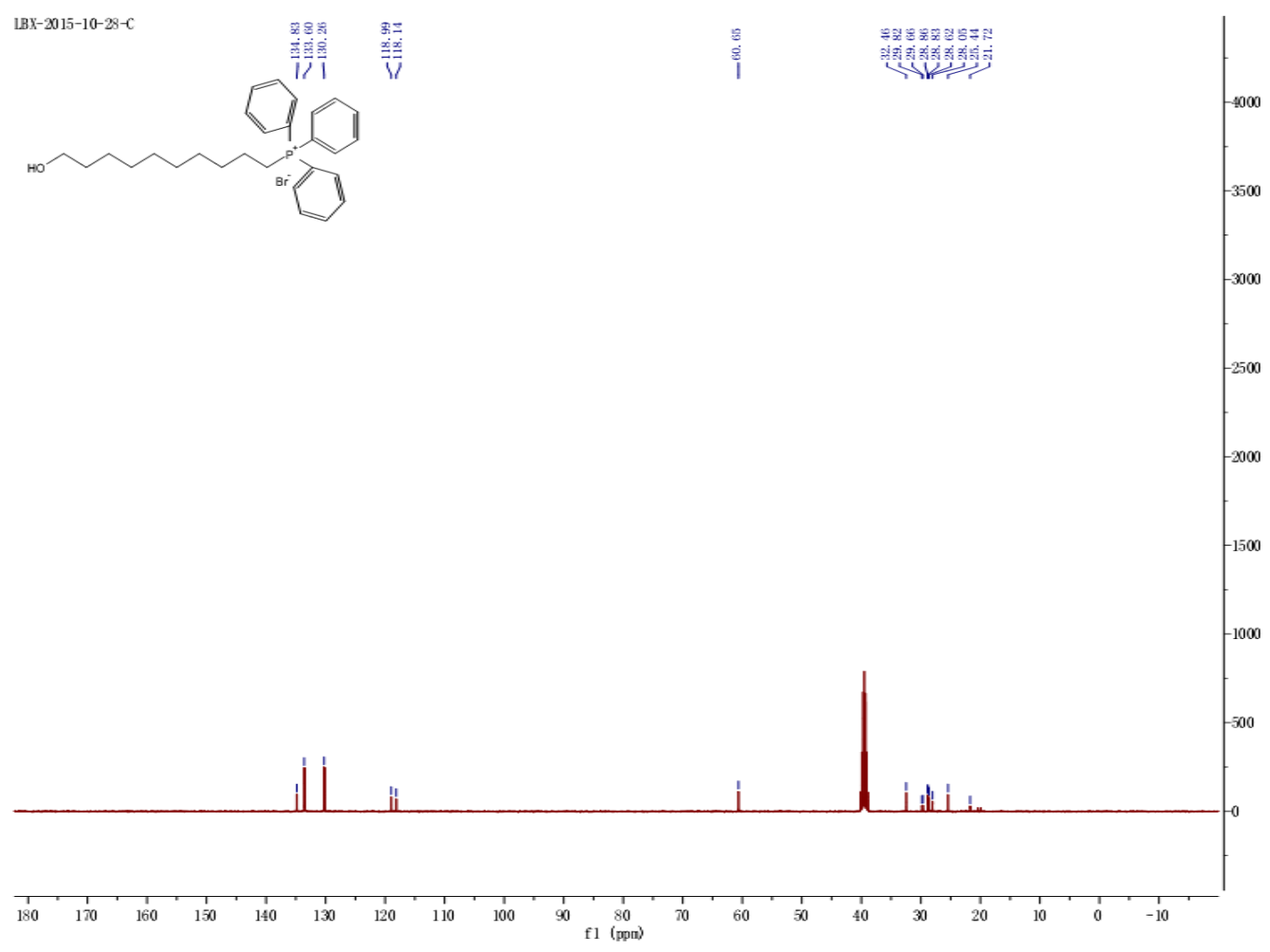

Figure S14. ${ }^{13} \mathrm{C}$ NMR spectrum of TPPOH in $\left(\mathrm{CD}_{3}\right)_{2} \mathrm{SO} .(101 \mathrm{MHz})$.

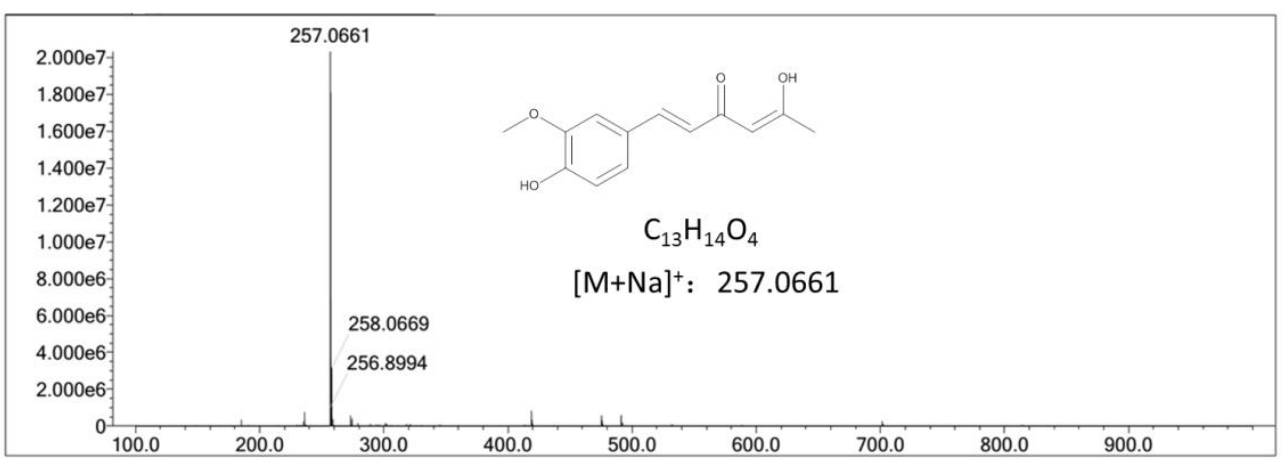

Figure S15. HRMS spectrum of M1.

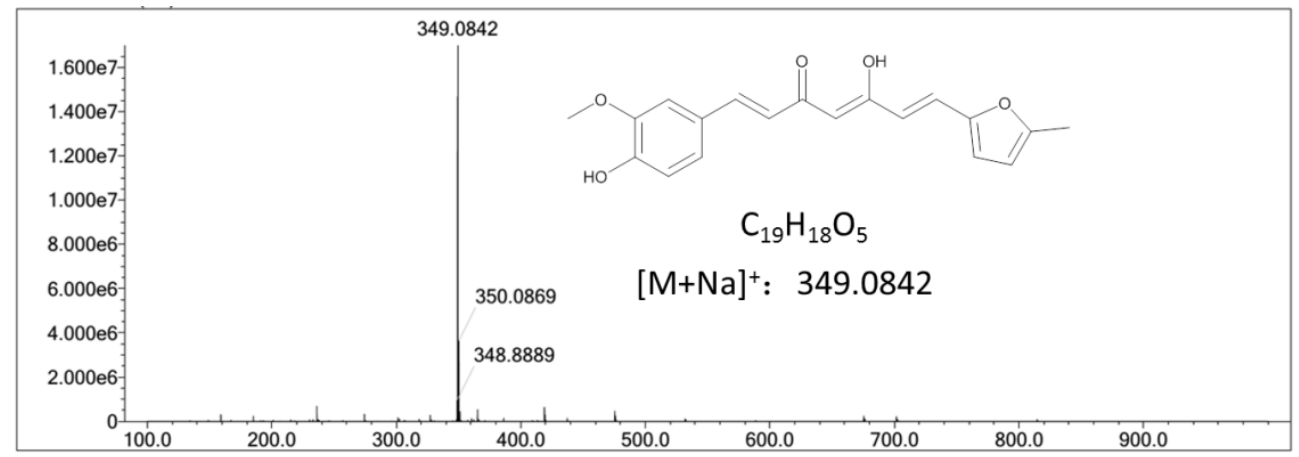

Figure S16. HRMS spectrum of 2a. 


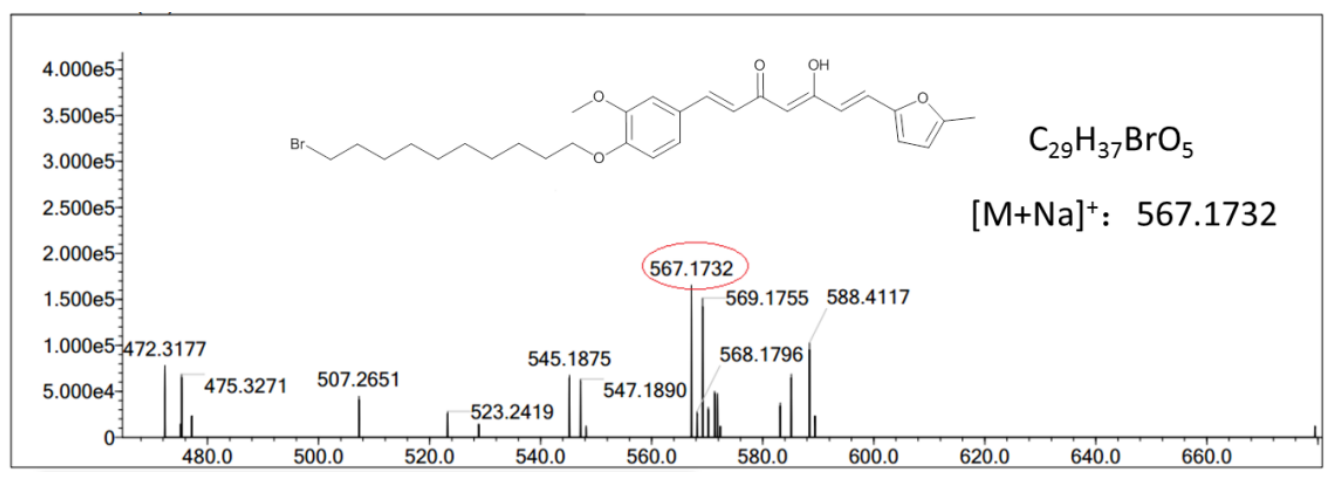

Figure S17. HRMS spectrum of M2.

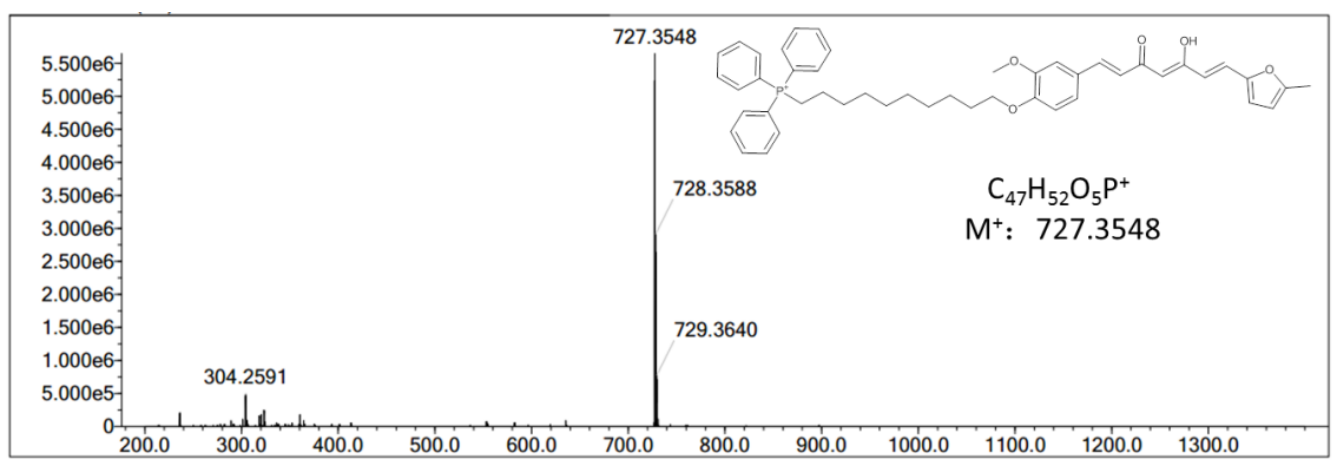

Figure S18. HRMS spectrum of TPP2a.

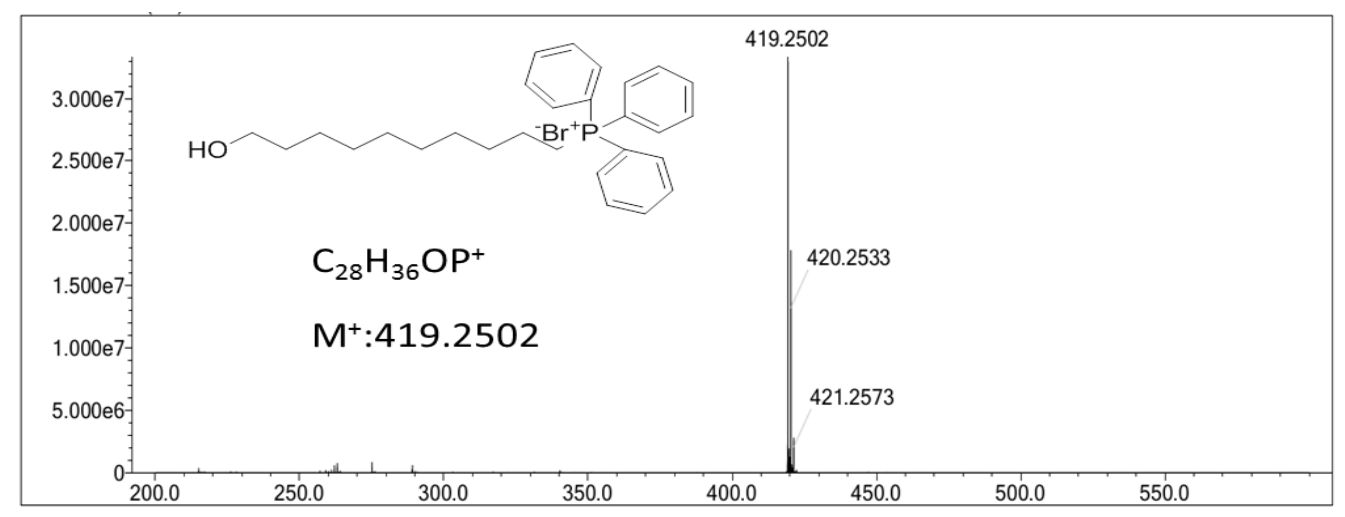

Figure S19. HRMS spectrum of TPPOH. 


\section{Supporting Information References}

1. Molecular Operating Environment (MOE), (2012, 10)Chemical Computing Group, Montreal, Quebec, Canada,

2. Lo, Y.-C., Ko, T.-P., Su, W.-C., Su, T.-L., and Wang, A. H.-J. (2009) Terpyridine-platinum (II) complexes are effective inhibitors of mammalian topoisomerases and human thioredoxin reductase 1, J. Inorg. Biochem. 103, 1082-1092.

3. Schrödinger, L. T. P. M. G. S., Version 1.2.r1,. ( 2009).

4. Benhar, M., Forrester, M. T., Hess, D. T., and Stamler, J. S. (2008) Regulated protein denitrosylation by cytosolic and mitochondrial thioredoxins, Science 320, 1050-1054.

5. Kipp, A. P., Müller, M. F., Göken, E. M., Deubel, S., and Brigelius-Flohé, R. (2012) The selenoproteins GPx2, TrxR2 and TrxR3 are regulated by Wnt signalling in the intestinal epithelium, Biochim. Biophys. Acta, Gen. Subj 1820, 1588-1596. 